\title{
DISTRIBUTION AND ECOLOGY OF CATAPSYDRAX INDIANUS, A NEW PLANKTONIC FORAMINIFER INDEX SPECIES FOR THE LATE OLIGOCENE-EARLY MIOCENE
}

\author{
Silvia Spezzaferri ${ }^{1,3}$ AND PAul N. PeArson ${ }^{2}$
}

\section{ABSTRACT}

The Oligocene-Miocene transition is characterized by a low degree of biotic turnover (extinction plus origination) in many microfossil groups and especially in planktonic foraminifera. Few species appear, evolve, and disappear across this boundary, and the existence of transitional forms between key species makes biostratigraphic resolution of the boundary interval difficult. The boundary is officially located in the type section using magnetostratigraphic criteria, and the first occurrence (FO) of the planktonic foraminifer Paragloborotalia kugleri is the closest bioevent to the boundary. The identification of supplementary bioevents is therefore important to refine the biostratigraphic resolution of this interval. We describe here a new species of planktonic foraminifer, Catapsydrax indianus, the range of which improves the biostratigraphic resolution across this problematic boundary. In particular, the distribution of this species spans an interval of approximately 5 million years across the Oligocene-Miocene transition from just above the FO of Paragloborotalia pseudokugleri (25.9 Ma) in the late Oligocene Biochron P22 (= Biochron O6) to the FO of Globigerinoides altiaperturus (20.5 Ma) in the early Miocene.

The habitat of this new species is inferred from its oxygen and carbon isotope values by comparison with the other species in a multispecies isotope cross-plot. Our data show that the deepest-dwelling of all the planktonic foraminifera was the genus Catapsydrax, which has relatively positive $\delta^{18} \mathrm{O}$ and negative $\delta^{13} \mathrm{C}$ values. Catapsydrax indianus has isotopic ratios similar to those of the other species in the genus, suggesting a similar habitat.

\section{INTRODUCTION}

The Oligocene-Miocene transition is a typical example of an epoch boundary that does not correspond to any major biological event. It is characterized instead by a low degree of biotic turnover (extinction plus origination) in many microfossil groups and especially within planktonic foraminifera (Spezzaferri, 1994, 1995). The low degree of biotic turnover and the strong discrepancies in species distributions that have been reported in the literature have resulted in the establishment of different zonations and compromised reliable correlations at a global scale (Spezzaferri, 1995). Spezzaferri (1994, 1995) suggested that latitudinal differences in the ranges of planktonic foraminifera can be related to climatic instability during the Oligocene-Miocene transition. In particular, lower Miocene Zone N4 (Fig. 1) was characterized by brief and alternating cool and warm

\footnotetext{
${ }^{1}$ Department of Geosciences, Earth Sciences, University of Fribourg, Chemin du Musée 6, 1700 Fribourg, Switzerland.

${ }^{2}$ School of Earth and Ocean Sciences, Cardiff University, Main Building, Park Place, Cardiff CF10 3YE, UK.

${ }^{3}$ Correspondence author. E-mail: silvia.spezzaferri@unifr.ch
}

episodes during a time of generally cool conditions. Zachos and others (2004) suggested that the Oligocene/Miocene boundary was a time of significant climatic change characterized by a brief but major Antarctic glaciation (Flower and others, 1997).

Since the pioneering work of Bolli (1957) in Trinidad, three species have been used to identify the Paleogene/ Neogene boundary, which equates to the Oligocene/ Miocene boundary: Globigerinoides primordius, Paragloborotalia kugleri, and Globoquadrina dehiscens.

It is common practice for a standard event (first or last occurrence [FO or LO] of the marker species) to be associated with additional bioevents to better place the boundary. Today, the FO of Globigerinoides primordius has been discarded because it occurs in the late Oligocene, as documented, for example, by Stainforth and others (1975), Lamb and Stainforth (1976), Berggren and others (1985), Iaccarino (1985), Premoli Silva and Spezzaferri (1990), Spezzaferri and Premoli Silva (1991), Spezzaferri (1994), and Spezzaferri (1996). In addition, the FO of Gq. dehiscens has also been discarded as a useful marker because of its geographic diachrony (e.g., Jenkins and Orr, 1972; Jenkins, 1978; Premoli Silva and Spezzaferri, 1990; Spezzaferri, 1994). In addition, this species is often rare and discontinuous at the beginning of its range. When it is absent, it is replaced by its presumed ancestor Globoquadrina praedehiscens, which is occasionally associated with forms transitional to $G$. dehiscens s.s. (Premoli Silva and Spezzaferri, 1990; Spezzaferri, 1994).

In 1997, the working group "In Search for the Paleogene/ Neogene Boundary" proposed to the International Commission on Stratigraphy (ICS) that the boundary be placed at the base of Magnetozone C6CN2n in the Lemme Section in Piedmont, Northern Italy (Steininger and others, 1997). When magnetostratigraphic data are missing, however, the identification of this boundary is very difficult, and additional bioevents should be considered. The FO of Paragloborotalia kugleri is $2 \mathrm{~m}$ above the base of this magnetozone, which makes it the most useful planktonic foraminiferal marker to identify this boundary (Steininger and others, 1997). Second-order bioevents (bioevents that are not used to define zonal boundaries) provide more detailed biostratigraphic control (e.g., Spezzaferri, 1994, 1996).

In this article, a new species of planktonic foraminifer, Catapsydrax indianus, is described, and its FO and LO are proposed as second-order bioevents useful in recognizing the late Oligocene/early Miocene boundary.

\section{MATERIAL AND METHODS}

This study emanates from a larger micropaleontological investigation aimed at identifying the planktonic biostratigraphy and the paleoclimatic record across the Oligocene/ 


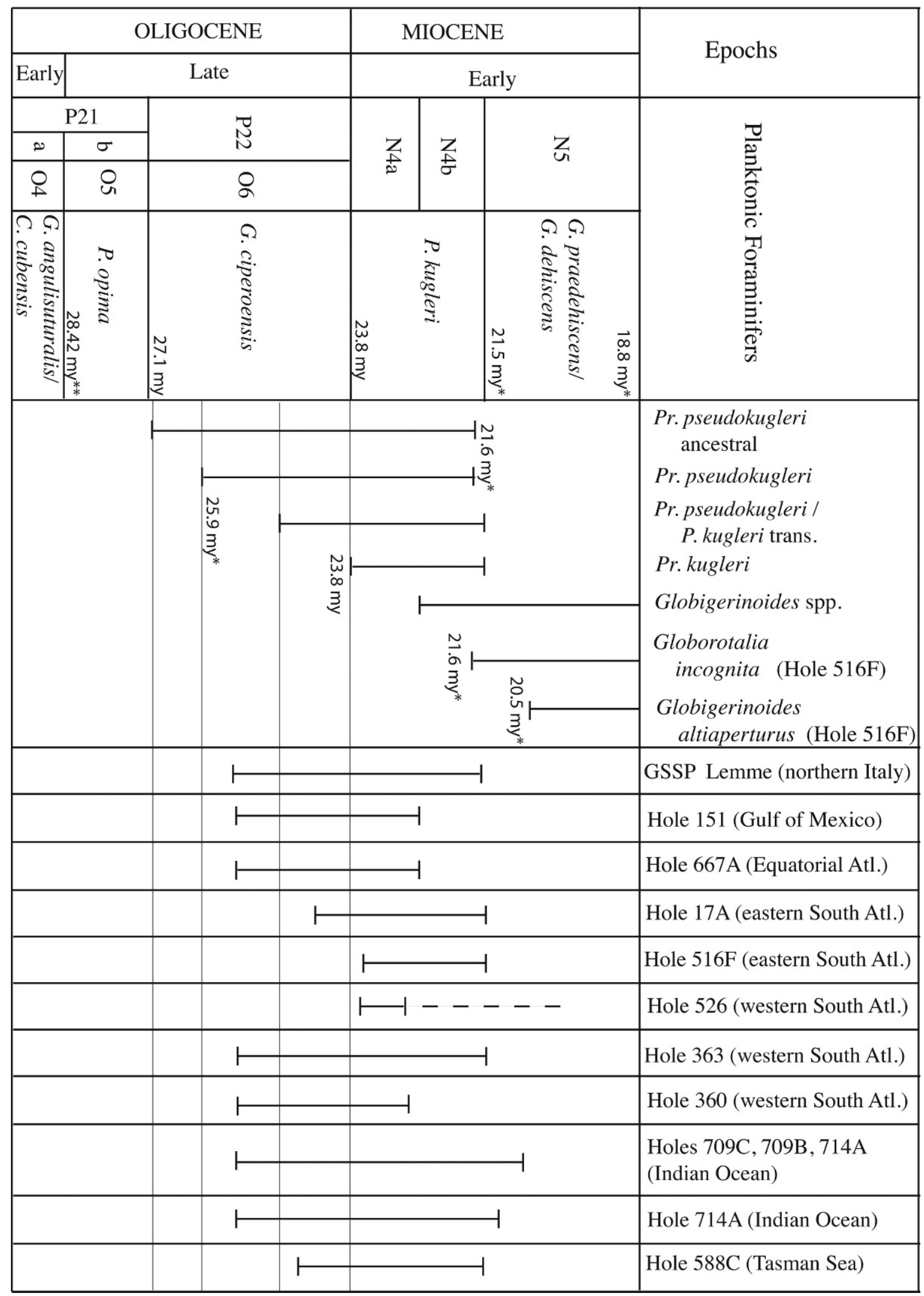

FIgure 1. Distribution of Catapsydrax indianus in the investigated sites. Oligocene zonation from Berggren and Pearson (2005, 2007) plotted versus the zonation proposed in Spezzaferri (1994). Miocene zonation from Spezzaferri (1994). Ages with * are from Berggren and others (1995). Ages with ** are from Wade and others (2007). The remaining ages are from Berggren and Pearson $(2005,2007)$. 
TABLE 1. Summary of the DSDP and ODP holes included in this study together with their latitude, longitude, water depth, studied cores, and geographic locations.

\begin{tabular}{lccccc}
\hline Holes/outcrops & Latitude & Longitude & Water depth (mbsf) & Studied cores & Location \\
\hline DSDP-151 & $15^{\circ} 01.02^{\prime} \mathrm{N}$ & $73^{\circ} 24.58^{\prime} \mathrm{W}$ & 2,029 & 4 to 9 & Gulf of Mexico \\
ODP-667A & $04^{\circ} 34.15^{\prime} \mathrm{N}$ & $21^{\circ} 54.68^{\prime} \mathrm{W}$ & $3,529.5$ & 35 to 26 & Equatorial Atlantic Ocean \\
DSDP-17A & $28^{\circ} 02.74^{\prime} \mathrm{S}$ & $36^{\circ} 15^{\prime} \mathrm{W}$ & 4,266 & 1 to 2 & Western South Atlantic Ocean \\
DSDP-516F & $30^{\circ} 16.59^{\prime} \mathrm{S}$ & $35^{\circ} 17.10^{\prime} \mathrm{W}$ & 1,313 & 1 to 20 & Western South Atlantic Ocean \\
DSDP-360 & $35^{\circ} 50.75^{\prime} \mathrm{S}$ & $18^{\circ} 05.79^{\prime} \mathrm{E}$ & 2,949 & 23 to 30 & Eastern South Atlantic Ocean \\
DSDP-363 & $19^{\circ} 38.75^{\prime} \mathrm{S}$ & $09^{\circ} 02.80^{\prime} \mathrm{E}$ & 2,248 & 1 to 5 & Eastern South Atlantic Ocean \\
DSDP-526A & $30^{\circ} 08.36^{\prime} \mathrm{S}$ & $03^{\circ} 08.28^{\prime} \mathrm{E}$ & 1,054 & 24 to 33 & Eastern South Atlantic Ocean \\
ODP-709C & $03^{\circ} 54.90^{\prime} \mathrm{S}$ & $60^{\circ} 33.10^{\prime} \mathrm{E}$ & $3,040.8$ & 18 to 27 & Equatorial Indian Ocean \\
ODP-709B & $03^{\circ} 54.90^{\prime} \mathrm{S}$ & $60^{\circ} 33.10^{\prime} \mathrm{E}$ & $3,040.8$ & 21 to 27 & Equatorial Indian Ocean \\
ODP-714A & $05^{\circ} 03.6^{\prime} \mathrm{N}$ & $73^{\circ} 47.2^{\prime} \mathrm{E}$ & $2,038.3$ & 19 to 24 & Equatorial Indian Ocean \\
ODP 588C & $26^{\circ} 06.7^{\prime} \mathrm{S}$ & $161^{\circ} 13.6^{\prime} \mathrm{E}$ & 1,533 & 1 to 17 & Tasman Sea \\
GSSP Lemme & $44^{\circ} 39.32^{\prime} \mathrm{N}$ & $8^{\circ} 50.11^{\prime} \mathrm{E}$ & N.A. & N.A. & Northern Italy \\
\hline
\end{tabular}

Miocene boundary based on planktonic foraminiferal distributions and abundances in deep-sea drilling and land sequences (Spezzaferri and Premoli Silva, 1991; Spezzaferri, 1994, 1995). The locations where the new species was found are listed in Table 1. In most cases, three samples per core section were examined. For those sequences characterized by the most carbonate dissolution or highest sedimentation rates, one or two samples per core section were investigated. Samples were prepared using the standard techniques for foraminiferal analyses (Spezzaferri, 1994).

Stable-isotope analysis was performed at Cardiff University on a MAT252 gas-source mass spectrometer with an automated KIEL carbonate preparation unit. Stable isotope results were calibrated to the PeeDee Belemnite (PDB) scale by the international standard NBS19, and analytical precision was $\pm 0.05 \%$ and $\pm 0.02 \%$ for $\delta^{18} \mathrm{O}$ and $\delta^{13} \mathrm{C}$, respectively.

\section{SYSTEMATIC PALEONTOLOGY \\ Catapsydrax indianus $\mathrm{n} . \mathrm{sp}$. Pl. 1, Figs. 1a-3c}

1979 Catapsydrax dissimilis subsp. 1, Molina, p. 289, P1. 25, figs. 3AD.

1990 Globorotaloides sp. 2, Premoli Silva and Spezzaferri, Pl. 3, figs. $7 \mathrm{a}-\mathrm{c}$.

1994 Catapsydrax sp. 1, Spezzaferri, Pl. 34, figs. 4a-b.

Holotype specimen. Plate 1, Figures 1a-c.

Derivation of the name. From the Indian Ocean, where it is very abundant.

Type level. Ocean Drilling Program (ODP) Sample 115709B-21-6, 78-80 cm.

Type section. ODP Hole 115-709B, Mascarene Plateau, water depth $3,040.8 \mathrm{~m}$, coordinates $03^{\circ} 54.9^{\prime} \mathrm{S}, 60^{\circ} 33.1^{\prime} \mathrm{E}$.

Sediment lithology. Nannofossil ooze.

Repository. Natural History Museum of Basel, Switzerland, Ref. C9820. The paratypes are also stored in Basel.

Diagnosis. The size of this species ranges from medium to large $(>250 \mu \mathrm{m})$; however, large specimens are generally more abundant. It displays a globigeriniform coiling mode with a moderately low trochospire consisting of about three whorls. The profile is subcircular and lobate with a rounded peripheral margin. Four subspherical chambers gradually increasing in size as added are present in the last whorl. The sutures are depressed and radial on both sides. The umbilicus is moderately deep and covered by a bulla in adult specimens. The primary aperture is a small and semicircular low umbilical arch, visible only when the bulla is broken or missing. Five accessory apertures, four opening over the sutures and one opening over the central part of the antepenultimate chamber, characterize this species. The size of the accessory apertural opening over the antepenultimate chamber varies in size from very small to wide, as in Plate 1, Figures $3 \mathrm{a}-\mathrm{b}$, or very irregular, as in Plate 1, Figure 2. The wall texture is strongly cancellate, with hexagonal pores located in deep pore pits. Although spines have not been observed in the studied specimens, Olsson and others (2007) regarded the genus Catapsydrax as probably spinose. When strong recrystallization overprints the original cancellate pattern, the wall texture shows euhedral crystals and inward growth of crystals replacing the earlier microgranular wall. Generally, the bulla is less coarsely cancellate than the rest of the test.

Remarks. This species differs from Catapsydrax dissimilis, Catapsydrax ciperoensis, and Catapsydrax unicavus in having five infralaminal accessory apertures instead of two, three to four, or one, respectively. It differs from $C$. unicavus by its more lobate profile.

Distribution. It ranges from the lower third of Zone P22 of Blow (1979), which corresponds to Zone O6 of Berggren and Pearson $(2005,2007)$, to Zone N5 of Blow (1979).

\section{BIOSTRATIGRAPHY}

Figure 1 shows the occurrence of Catapsydrax indianus plotted against (1) the evolutionary stages of Paragloborotalia kugleri as in Spezzaferri (1991, 1994), (2) the diversification level of the genus Globigerinoides as in Spezzaferri (1994), and (3) the FOs of Globorotalia incognita and Globigerinoides altiaperturus in Hole $516 \mathrm{~F}$.

In Hole 516F, these species' FOs are at 21.6 Ma and $20.5 \mathrm{Ma}$, respectively (Berggren and others, 1995). The FO of $C$. indianus occurs between the FO of Paragloborotalia pseudokugleri $(25.9 \mathrm{Ma})$ and the $\mathrm{FO}$ of P. pseudokugleri-P. kugleri transition forms (Appendix 1) in the sediments from the Global Stratotype Sction and Point (GSSP) Lemme section (northern Italy), at Deep Sea Drilling Project (DSDP) Hole 151 (Gulf of Mexico), ODP Hole 667A (equatorial Atlantic), DSDP Holes 363 and 360 (eastern South Atlantic Ocean), and ODP Holes 709C, 709B, and 714A (Indian Ocean). At DSDP Hole 17A and ODP Hole 

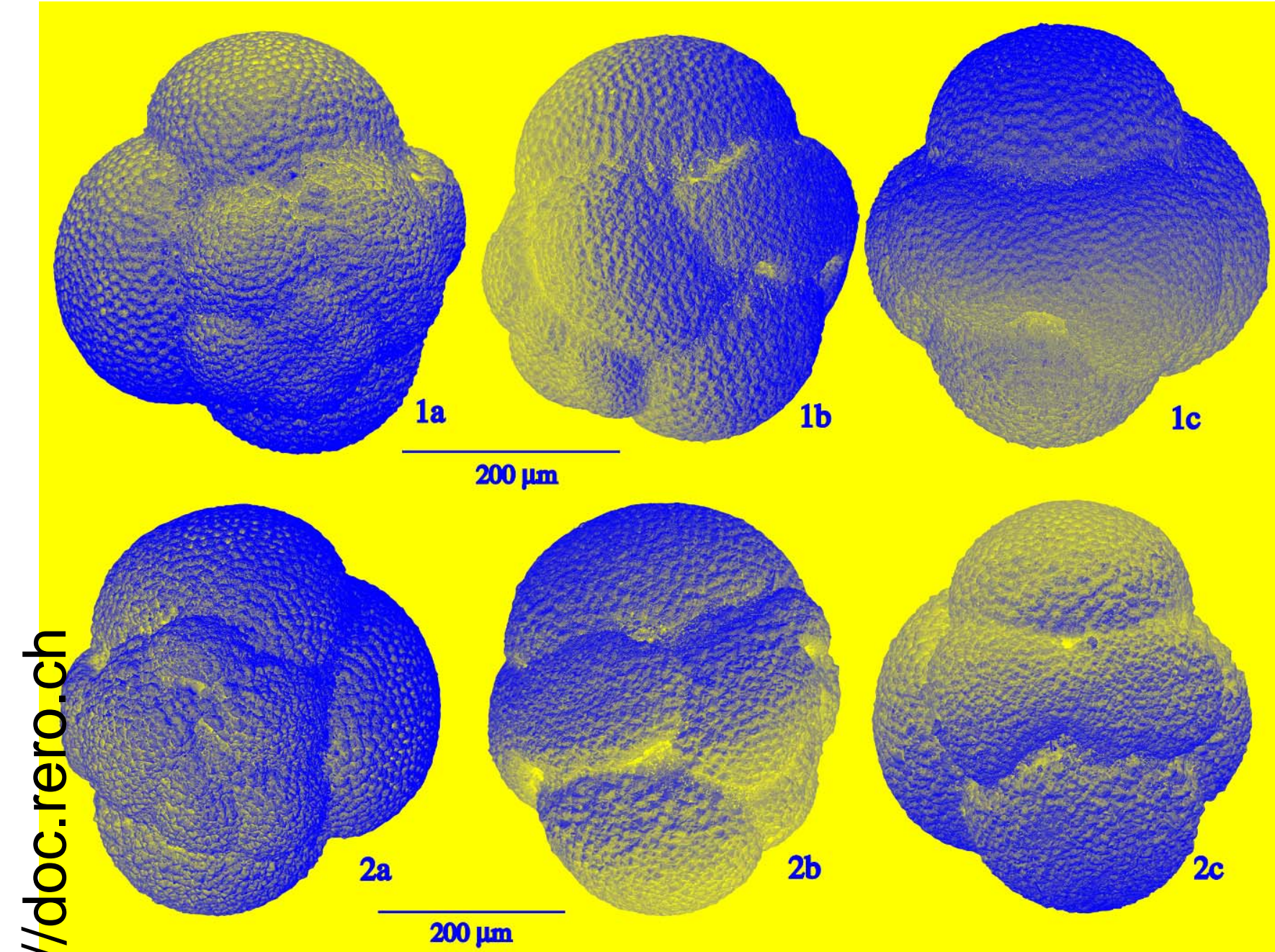

을
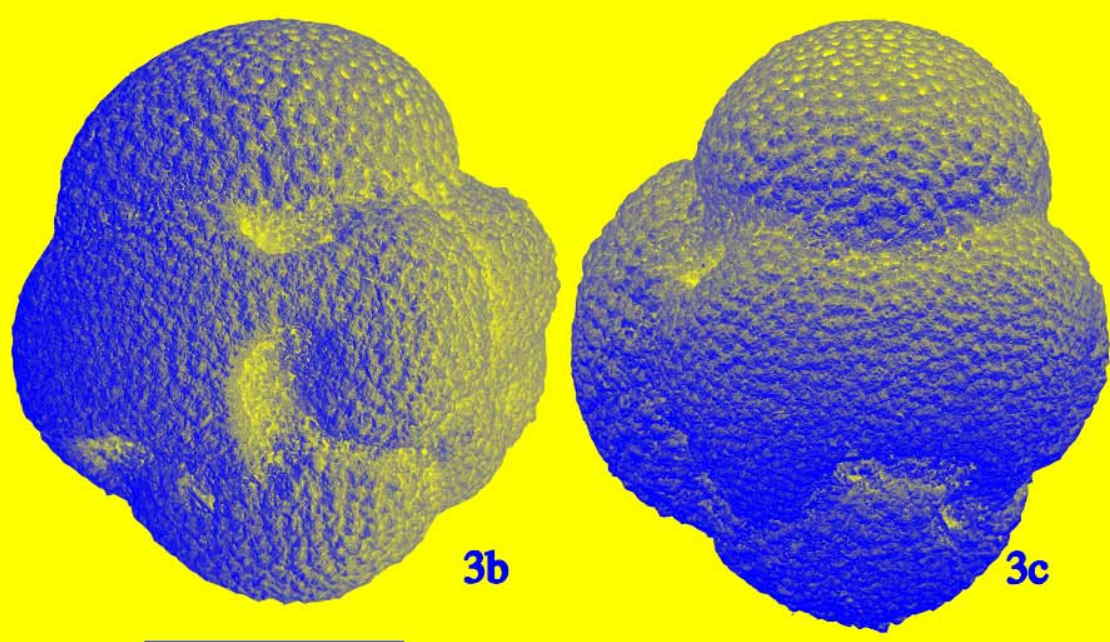

\section{$200 \mu \mathrm{m}$}

PLATE 1

Holotype and paratypes of Catapsydrax indianus. 1a-c Catapsydrax indianus Spezzaferri and Pearson, holotype, ODP Sample 115-709B-21-6, 7880 cm: 1a spiral view, 1b side view, 1c umbilical view. 2a-c Catapsydrax indianus Spezzaferri and Pearson, paratype, ODP Sample115-709B-21-6, 7880 cm: 2a spiral view, 2b side view, 2c umbilical view. 3a-c Catapsydrax indianus Spezzaferri and Pearson, paratype, ODP Sample115-709B-21-6, 78$80 \mathrm{~cm}$ : 3a spiral view, 3b side view, 3c umbilical view. 


\section{ODP Sample 155-709B-21X-6, 78-80 cm Mascarene Plateau}

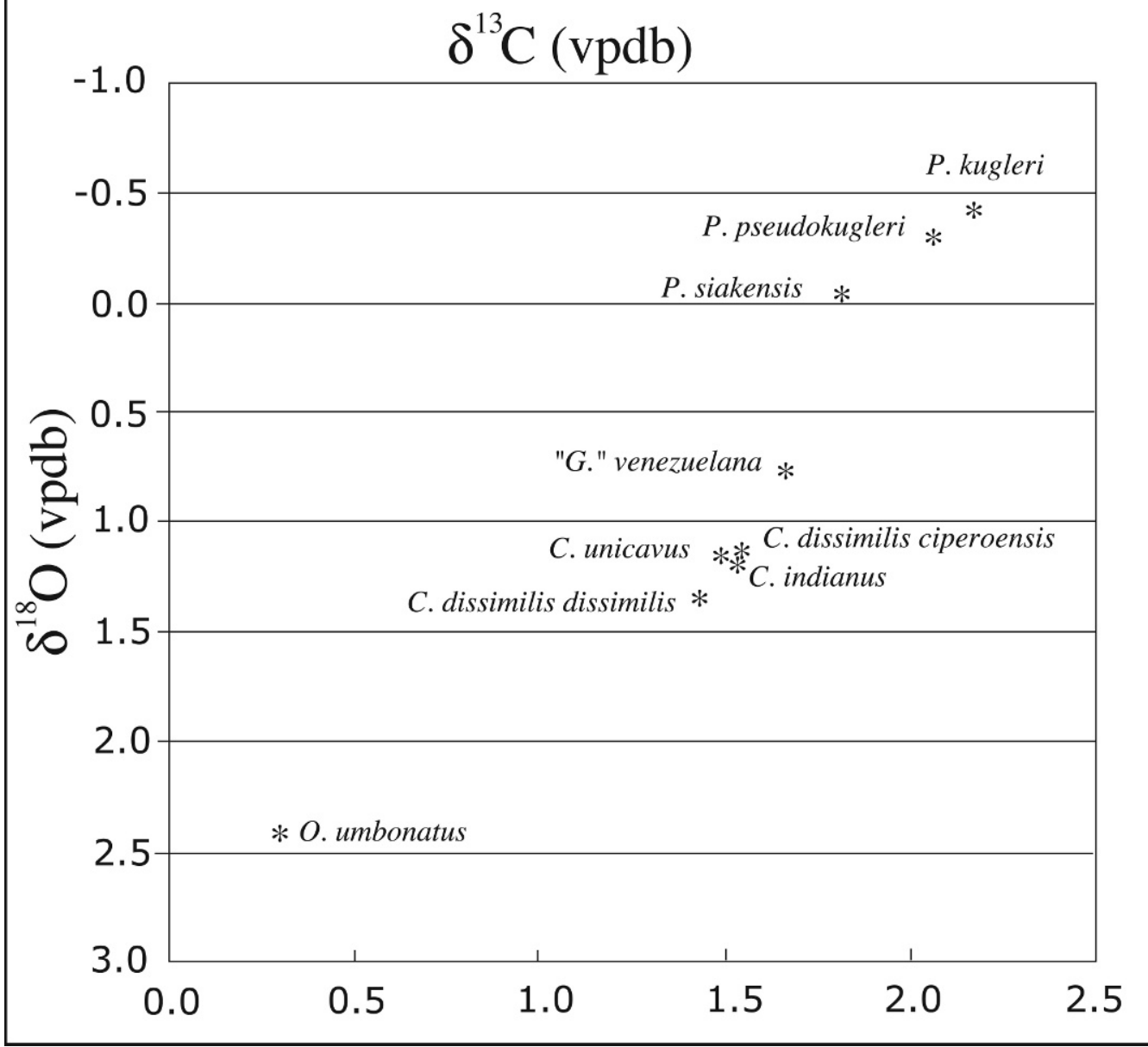

FIGURE 2. Oxygen- and carbon-isotope cross-plot of planktonic foraminifers and Oridorsalis umbonatus from ODP Sample 115-709B-21-6, 78$80 \mathrm{~cm} . \mathrm{vpdb}=$ Vienna PeeDee Belemnite.

$588 \mathrm{C}, C$. indianus first occurs between the $\mathrm{FO}$ of the $P$. pseudokugleri-P. kugleri transition and the FO of $P$. kugleri (23.8 Ma). At DSDP Holes 516F and 526A, it first occurs between the FO of $P$. kugleri and the diversification level of the Globigerinoides. The LO of $C$. indianus is at the top of Zone N4b (21.5 Ma) at the GSSP Lemme section, DSDP Holes 17A, 516F, and 363, and ODP Holes 714B and 588C. It is at the top of Zone N4a at DSDP Hole 360 and within Zone N4a at DSDP Hole 526A.

\section{MULTI-SPECIES ISOTOPE ANALYSES}

Multi-species carbon- and oxygen-isotope analyses were performed on the eight planktonic species listed in Table 2 and on the benthic foraminifer Oridorsalis umbonatus in order to determine the likely habitat of the new species relative to other common species in the same assemblage. Figure 2 shows a $\delta^{18} \mathrm{O}$ versus $\delta^{13} \mathrm{C}$ plot of those eight planktonic foraminifers from a single sediment sample
(ODP Sample 115-709B-21X-6, 78-80 cm). Among the planktonic foraminifera, Catapsydrax dissimilis, C. ciperoensis, $C$. indianus, and $C$. unicavus are the most positive with respect to $\delta^{18} \mathrm{O}$, most negative with respect to $\delta^{13} \mathrm{C}$, and the closest to the values of $O$. umbonatus. The species showing values most negative with respect to $\delta^{18} \mathrm{O}$ and most positive with respect to $\delta^{13} \mathrm{C}$ are $P$. kugleri, $P$. pseudokugleri, and Paragloborotalia siakensis. Globoquadrina venezuelana has carbon and oxygen isotopic values intermediate between these two groups.

\section{DISCUSSION}

\section{BIOSTRATIGRAPHY}

In the identification of the Oligocene-Miocene transition, standard bioevents (first and last occurrences [FO and LO] of the marker species) have often been associated with second-order bioevents (e.g., Spezzaferri, 1994; Steininger and others, 1997). For example, the diversification level of 
TABLE 2. Oxygen- and carbon-isotope data used in the cross-plot for the multi-species investigation. vpdb $=$ Vienna PeeDee Belemnite.

\begin{tabular}{lcc}
\hline \multicolumn{1}{c}{ Species } & $\delta^{13} \mathrm{C}(\mathrm{vpdb}, \%)$ & $\delta^{18} \mathrm{O}(\mathrm{vpdb}, \%)$ \\
\hline$P$. kugleri & 2.065 & -0.3195 \\
P. pseudokugleri & 2.169 & -0.429 \\
P. siakensis & 1.82 & -0.041 \\
G. venezuelana & 1.67 & 0.759 \\
C. ciperoensis & 1.549 & 1.153 \\
C. dissimilis & 1.437 & 1.326 \\
C. unicavus & 1.497 & 1.13 \\
C. indianus & 1.536 & 1.169 \\
O. umbonatus & 0.259 & 2.385 \\
\hline
\end{tabular}

the genus Globigerinoides worldwide falls within the upper two-thirds of Zone N4, an interval delimited by the FO and LO of Paragloborotalia kugleri (Spezzaferri, 1994). The evolutionary stages of this latter species have been summarized in Spezzaferri (1991) from the first small and simple ancestral forms to the more evolved and complex morphotypes occurring at the end of its range.

By comparing these second-order bioevents with the FO and LO of Catapsydrax indianus, we observe that the FO of this new species occurs between the FOs of Paragloborotalia pseudokugleri and the P. pseudokugleri-P. kugleri transitional morphotype in seven out of the eleven holes where the species has been observed. Its LO occurs approximately in the same position in six holes with respect to the evolutionary stages of the $P$. kugleri group and the diversification level of Globigerinoides (Fig. 1). In summary, the distribution of this species spans an interval of approximately 5 million years, from just above the FO of P. pseudokugleri (25.9 Ma) in Biochron $\mathrm{P} 22$ to the $\mathrm{FO}$ of $G$. altiaperturus (20.5 Ma) across the late Oligocene/early Miocene boundary.

Reasons for the discrepancy in the position of its FO and LO in some holes or regions might include reworking and winnowing; sampling resolution, availability, and/or faunal preservation; or paleoceanographic setting. These possibilities are summarized as follows.

1. Reworking and winnowing. These physical processes may affect the relative distribution of planktonic foraminifers. For example, winnowing has displaced and redeposited to various degrees the sediments from Hole 526A (Moore and others, 1984).

2. Sampling resolution, availability, andlor faunal preservation. At Hole 17A, the faunal preservation is generally very poor, and many tests show significant dissolution effects. Holes 360 and 363 have not been continuously cored through Zone N4b (Bolli and others, 1978). Hiatuses truncate the sedimentary sequence for most of Zone N4 at Hole 714A, the upper part of Zone P22, and the base of Zone N4a at Holes 151 and $516 \mathrm{~F}$.

3. Paleoceanographic setting. This species is typical of cold-water, but it has not been documented from upwelling regions (Spezzaferri, 1995). Its absence in sediments from Holes $667 \mathrm{~A}$ and $516 \mathrm{~F}$ is probably related to the upwelling regime in the equatorial and western South Atlantic Ocean, respectively.

\section{Stable Isotope Paleobiology}

The depth habitat of planktonic foraminifera can be inferred from their oxygen-isotope values (see, for example, Emiliani, 1954; Berger and others, 1978; Douglas and Savin, 1978; Poore and Matthews, 1984; Pearson and others, 1993, 1997). In particular, the species with the lightest $\delta^{18} \mathrm{O}$ values probably calcified in the warmest water (i.e., the surface mixed layer) with respect to the others. Species with heavier $\delta^{18} \mathrm{O}$ values probably calcified their tests in deeper, cooler waters below the thermocline. The $\delta^{13} \mathrm{C}$ values may also partly reflect the different preferred depths of calcification of planktonic foraminiferal species. The $\delta^{13} \mathrm{C}$ value of dissolved inorganic carbon tends to decrease rapidly with depth below the euphotic zone, where the remineralization of isotopically light organic matter occurs in the absence of photosynthesis (Kroopnick, 1985; Pearson and Wade, in press).

Although recrystallization affects to varying degrees the tests of the planktonic foraminifers in the samples from the Indian Ocean (e.g., ODP Sample 115-709B-21X-6, 78$80 \mathrm{~cm}$ ), the relative ordering of the different species in the oxygen- and carbon-isotope cross-plot (Fig. 2) is generally robust for inferring life habitats. Figure 2 compares these results with the findings of similar studies of Oligocene planktonic foraminifera (e.g., Douglas and Savin, 1978; Poore and Matthews, 1984; Corfield and Cartlidge, 1991; Pearson and others, 1997).

Overall, the differences in the life habitat among species as inferred from the oxygen- and carbon-isotope cross-plot (Fig. 2) are much reduced compared to the well-preserved sample from Trinidad studied by Pearson and Wade (in press) but similar to the assemblage from ODP Site 926 (Ceara Rise) studied by Pearson and others (1997). This is attributed to diagenetic recrystallization, which has reduced but not obliterated the interspecific differences here and at the Ceara Rise, allowing us to infer relative depth habitats (see Pearson and others, 2001, for discussion of this diagenetic effect.)

Paragloborotalia pseudokugleri and P. kugleri have the most negative $\delta^{18} \mathrm{O}$ values, suggesting that they inhabited the surface mixed layer. Paragloborotalia siakensis has slightly less negative $\delta^{18} \mathrm{O}$ values (as it does, for example, in Trinidad; Pearson and Wade, in press), suggesting that it may have calcified a greater proportion of its shell calcite at depth. "Globoquadrina" venezuelana was a deep-dwelling, non-symbiotic form. The deepest-dwelling of all the planktonic foraminifera was the genus Catapsydrax, which has relatively positive $\delta^{18} \mathrm{O}$ and negative $\delta^{13} \mathrm{C}$ values. Catapsydrax indianus has isotopic ratios similar to those of the other species in this genus, suggesting their similar habitat.

\section{CONCLUSIONS}

A new species of planktonic foraminifer, Catapsydrax indianus, which occurs across the late Oligocene-early Miocene transition, is described. Its distribution spans an interval of approximately 5 million years across the late Oligocene-early Miocene transition from just above the FO of Paragloborotalia pseudokugleri (25.9 Ma) in Biochron 
P22 (Zone O6) to the FO of Globigerinoides altiaperturus (20.5 Ma). Therefore, its FO and LO may serve as secondorder bioevents for identifying this interval.

Multispecies isotope data from ODP Sample 115-709B$21-6,78-80 \mathrm{~cm}$ suggest that Catapsydrax indianus has isotopic ratios similar to those of the other species of the genus Catapsydrax, which indicates a similar deep-dwelling habitat.

\section{ACKNOWLEDGMENTS}

We thank the DSDP and ODP for providing the large number of samples from holes around the world oceans. Thanks are due to the members of the Paleogene Planktonic Foraminifera Working Group for discussion and advice. A warm thank you is extended to Isabella Premoli Silva and the University of Milano for financial support (Ph.D. thesis of the senior author from 1989 to 1992). Scanning electron microscope (SEM) images were obtained at the University of Fribourg, Switzerland, with the valuable help of Christoph Neururer. Isotope measurements were obtained at the University of Cardiff by Julia Becker.

\section{REFERENCES}

Berger, W. H., Killingley, J. S., and Vincent, E., 1978, Stable isotopes in deep sea carbonates: box core ERDC-92, west equatorial Pacific: Oceanologica Acta, v. 1, p. 203-216.

Berggren, W. A., Kent, D. V., and Van Couvering, J. A., 1985, Neogene geochronology and chronostratigraphy, in Snelling, N. J. (ed.), The Chronology of the Geological Record, Memoir 10: Geological Society of London, London, UK, p. 211-260.

Swisher, C. C., III, and Aubry, M.-P., 1995, A revised Cenozoic geochronology and chronostratigraphy, in Berggren, W. A., Kent, D. V., Swisher, C. C., III, Aubry, M.-P., and Hardenbol, J. (eds.), Geochronology, Time Scales and Global Stratigraphic Correlation, Special Publication 54: SEPM (Society for Sedimentary Geology), Tulsa, OK, p. 129-212.

- and PeArson, P. N., 2005, A revised tropical to subtropical Paleogene planktonic foraminiferal zonation: Journal of Foraminiferal Research, v. 35, p. 279-298.

, and $\longrightarrow$ 2007, Tropical to subtropical planktonic foraminiferal zonation of the Eocene and Oligocene, in Pearson, P. N., Olsson, R. K., Huber, B. T., Hemleben, C., and Berggren, W. A. (eds.), Atlas of Eocene Planktonic Foraminifera, Cushman Foundation for Foraminiferal Research, Special Publication No. 41: Allen Press, Lawrence, KS, p. 29-40.

Blow, W. H., 1979, The Cainozoic Globigerinida: E.J. Brill, Leiden, $1413 \mathrm{p}$.

Bolli, H. M., 1957, Planktonic foraminifera from the OligoceneMiocene Cipero and Lengua formations of Trinidad, B.W.I., in Loeblich, A. R. Jr., Tappan, H., Beckmann, J. P., Bolli, H. M., Gallitelli, E. M., and Troelsen, J. C. (eds.), Studies in Foraminifera: U.S. National Museum Bulletin 215, p. 97-123.

- - RyAN, W. B. F., and others, 1978, Initial Reports of the Deep Sea Drilling Project, v. 40: U.S. Government Printing Office, Washington, D.C., 1079 p.

Corfield, R. M., and Cartlidge, J. E., 1991, Isotopic evidence for the depth stratification of fossil and Recent Globigerinina: a review: Historical Biology, v. 5, p. 37-63.

Douglas, R. G., and SAVIN, S. M., 1978, Oxygen isotopic evidence for the depth stratification of the Tertiary and Cretaceous planktic foraminifera: Marine Micropaleontology, v. 3, p. 175-196.

Emiliani, C., 1954, Depth habitats of some species of pelagic foraminifers as indicated by oxygen isotopic ratios: American Journal of Science, v. 252, p. 149-158.

Flower, B. P., Zachos, J. C., and Martin, H., 1997, Latest Oligocene through early Miocene isotopic stratigraphy and deep-water paleoceanography of the western equatorial Atlantic: Sites 926 and 929, in Shackleton, N. J. H., Curry, W. B., Richter, C., and Bralower, T. J. (eds.), Proceedings of the Ocean Drilling Program, Scientific Results, v. 154: Ocean Drilling Program, College Station, Texas, p. 451-461.

Iaccarino, S., 1985, Mediterranean Miocene and Pliocene planktic foraminifera, in Bolli, H. M., Saunders, J. B., and Perch-Nielsen, K. (eds.), Plankton Stratigraphy: Cambridge University Press, Cambridge, p. 283-314.

JENKINS, D. G., 1978, Neogene planktonic foraminifers from DSDP Leg 40 Sites 360 and 363 in the southeastern Atlantic, in Bolli, H. M., Ryan, W. B. F., and others. (eds.), Initial Reports of the Deep Sea Drilling Project, v. 40: U.S. Government Printing Office, Washington, D.C., p. 723-740.

- , and ORR, W. N., 1972, Planktonic foraminiferal biostratigraphy of the eastern equatorial Pacific, DSDP Leg 9, in Hays, J. D., Cook, H. J., and others. (eds.), Initial Reports of the Deep Sea Drilling Project, v. 9: U.S. Government Printing Office, Washington, D.C., p. 1059-1196.

Kroopnick, P. M., 1985, The distribution of ${ }^{13} \mathrm{C}$ of $\Sigma \mathrm{CO}_{2}$ in the world oceans: Deep-Sea Research, v. 32, p. 57-84.

LAmb, J. M., and Stainforth, R. M., 1976, Unreliability of Globigerinoides datum: Bulletin of the American Association of Petroleum Geologists, v. 60, no. 9, p. 1564-1569.

Moore, T. C., Rabinowitz, P. D., and others, 1984, Initial Reports of the Deep Sea Drilling Project, v. 74: U.S. Government Printing Office, Washington, D.C., 893 p.

Olsson, R. K., Pearson, P. N., and Huber, B. T., 2007, Taxonomy, biostratigraphy, and phylogeny of Eocene Catapsydrax, Globorotaloides, Guembelitrioides, Paragloborotalia, Parasubbotina, and Pseudoglobigerinella n. gen., in Pearson, P. N., Olsson, R. K., Huber, B. T., Hemleben, C., and Berggren, W. A. (eds.), Atlas of Eocene Planktonic Foraminifera, Cushman Foundation for Foraminiferal Research, Special Publication No. 41: Allen Press, Lawrence, KS, p. 67-110.

Pearson, P. N., Ditchfield, P. W., Singano, J., Harcourt-Brown, K., Nicholas, C. J., Olsson, R. K., Shackleton, N. J., and HALl, M. A., 2001, Warm tropical sea surface temperatures in the Late Cretaceous and Eocene epochs: Nature, v. 413, p. 481-487. -, Shackleton, N. J., and Hall, M. A., 1993, Stable isotope paleoecology of middle Eocene planktonic foraminifera and multispecies isotope stratigraphy, DSDP Site 523, South Atlantic: Journal of Foraminiferal Research, v. 23, p. 123-140.

, Weedon, G. P., and Hall, M. A., 1997, Multispecies planktonic foraminifera stable isotope stratigraphy through Oligocene/Miocene boundary climatic cycles, Site 926, in Shackleton, N. J. H., Curry, W. B., Richter, C., and Bralower, T. J. (eds.), Proceedings of the Ocean Drilling Program, Scientific Results, v. 154: Ocean Drilling Program, College Station, Texas, p. 441-449.

- , and WADE, B. S., in press, Taxonomy and stable isotope paleoecology of well-preserved planktonic foraminifera from the uppermost Oligocene of Trinidad: Journal of Foraminiferal Research, v. 39.

Poore, R. Z., and Matthews, R. K., 1984, Oxygen isotope ranking of late Eocene and Oligocene planktonic foraminifers: implications for Oligocene sea-surface temperatures and global ice-volume: Marine Micropaleontology, v. 9, p. 111-134.

Premoli Silva, I., and Spezzaferri, S., 1990, Paleogene planktonic foraminifer biostratigraphy and paleoenvironmental remarks on Paleogene sediments from Indian Ocean Sites, Leg 115, in Backman, J., Duncan, R. A., and Peterson, L. C. (eds.), Proceedings of the Ocean Drilling Program, Scientific Results, v. 115: Ocean Drilling Program, College Station, Texas, p. 277-314.

Spezzaferri, S., 1991, Evolution and taxonomy of Paragloborotalia kugleri (Bolli): Journal of Foraminiferal Research, v. 21, no. 4, p. 313-318.

, 1994, Planktonic foraminiferal biostratigraphy and taxonomy of the Oligocene and lower Miocene in the oceanic record. An overview: Palaeontographia Italica, v. 81, 187 p.

, 1995, Planktonic foraminiferal paleoclimatic implications across the Oligocene/Miocene transition in the oceanic record (Atlantic, Indian and South Pacific): Palaeogeography, Palaeoclimatology, Palaeoecology, v. 114, p. 43-74. 
1996, The Oligocene/Miocene boundary in the Lemme section (Piedmont basin, northern Italy): paleoclimatic evidence based on planktonic foraminifera: Giornale di Geologia, v. 58, no. 1/2, p. 119-139.

, and Premoli Silva, I., 1991, Oligocene planktonic foraminiferal biostratigraphy and paleoclimatic interpretation from Hole 538A, DSDP Leg 77, Gulf of Mexico: Palaeogeography, Palaeoclimatology, Palaeoecology, v. 83, p. 217-263.

Stainforth, R. M., Lamb, J. L., Luterbacher, H. P., BeArd, J. H., and JefFords, R. M., 1975, Cenozoic planktonic foraminiferal zonation and characteristics of index form, Paleontological Contribution Art. 62: University of Kansas, Lawrence, $\mathrm{KS}, 425 \mathrm{p}$.

Steininger, F. F., Aubry, M. P., Berggren, W. A., Biolzi, M., Borsetti, A. M., Brzobohaty, R., Cartlidge, J. E., Cati, F., Corfield, R., Gelati, R., Iaccarino, S., Modden, C.,

\section{APPENDIX}

Taxonomic notes on the transitional form Paragloborotalia pseudokugleri (Blow)/P. kugleri (Bolli)

Since the transitional form P. pseudokugleri (Blow)/P. kugleri (Bolli) is not a formal taxon, a short description is presented here following Spezzaferri (1991, 1994). Paragloborotalia pseudokugleri (Blow)/P. kugleri (Bolli) shows transitional characters between P. pseudokugleri (Blow) and P. kugleri (Bolli). In particular, it is characterized by a very low trochospire and plano-convex test, subovate chambers arranged in
Napoleone, D., Nolf, F., Ottner, B., Reichenbacher, B., Rögl, F., Roetzel, R., Spezzaferri, S., Tateo, F., Villa, G., Wielandt, U., Zevenboom, D., and ZoRn, I., 1997, The global stratotype section and point the G S S P for the base of the Neogene (the Paleogene/Neogene boundary): Episodes, v. 20, p. 23-28.

Wade, B. S., Berggren, W. A., and Olsson, R. K., 2007, The biostratigraphy and paleobiology of Oligocene planktonic foraminifera from the equatorial Pacific Ocean (ODP Site 1218): Marine Micropaleontology, v. 62, p. 167-179.

Zachos, J. C., Shackleton, N. J., Revenaugh, J. S., Palike, H., and Flower, B. P., 2004, Climate response to orbital forcing across the Oligocene-Miocene boundary: Science, v. 292, p. 274-278.

two-and-a-half whorls. Six and a half chambers in the last whorl increase slowly in size. The sutures are slightly arched to arched on the spiral side and straight on the umbilical side. The peripheral margin is rounded to slightly subacute. It has a low arched and umbilical to extraumbilical aperture, sometimes bordered by a thin lip and a narrow umbilicus. For comparison, Paragloborotalia kugleri is slightly to strongly biconvex, with six to eight subovate chambers in the last whorl. Sutures are slightly depressed and very arched on the spiral side and slightly arched on the umbilical side. Its peripheral margin is subacute. 